ISSN: 2339-2541

JURNAL GAUSSIAN, Volume 8, Nomor 4, Tahun 2019, Halaman 428 - 438

Online di: http://ejournal3.undip.ac.id/index.php/gaussian

\title{
IMPLEMENTASI METODE SAW DAN WASPAS DENGAN PEMBOBOTAN ROC DALAM SELEKSI PENERIMAAN PESERTA DIDIK BARU \\ (Studi Kasus: Madrasah Tsanawiyah (MTs) Negeri Kisaran Kabupaten Asahan Provinsi Sumatera Utara Tahun Ajaran 2018/2019)
}

\author{
Eva Salsa Nabila ${ }^{1}$, Rita Rahmawati ${ }^{2}$, Tatik Widiharih ${ }^{3}$ \\ ${ }^{1,2,3}$ Departemen Statistika FSM Universitas Diponegoro \\ ritarahmawati@gmail.com
}

\begin{abstract}
Multi Attribute Decision Making (MADM) is one of the decision-making methods to determine the best alternative from a number of alternatives based on certain criteria. There are several methods that can be used to solve MADM problems including Simple Additive Weighting (SAW) and Weighted Aggregated Sum Product Assesmen (WASPAS). Both methods are applied in the selection of prospective new students. In this study, MTsN Kisaran selected 192 students received from 422 registrans and determined certain criteria to get quality students. The criteria determined are the value of the national exam, the value of the Al-Qur'an test, and the value of the academic potential test. The method applied is SAW and WASPAS with the weighting Rank Order Centroid (ROC). Then a sensitivity analysis is carried out to determine a viable methods selected to obtain optimal results. This research was designed with the help of the Matlab GUI as a computing tool to simplify and accelerate the selection process. Based on the results of the study, the average percentage value of sensitivity for the SAW method was $-0.82 \%$ while the WASPAS method was $-0.87 \%$. With the existence of sensitivity analysis it can be known the most appropriate method for this case is the SAW method.
\end{abstract}

Keywords: Students, SAW, WASPAS, ROC, Sensitivity, GUI Matlab.

\section{PENDAHULUAN}

Pendidikan merupakan hal yang sangat penting untuk manusia karena dapat menciptakan manusia yang berkualitas dan berintelektual. Penentuan calon peserta didik baru memerlukan adanya beberapa pertimbangan untuk persyaratan masuk sekolah. Madrasah Tsanawiyah (MTs) Negeri Kisaran merupakan salah satu lembaga pendidikan yang berada di Kabupaten Asahan dan termasuk sekolah yang setiap tahunnya membuka penerimaan calon peserta didik baru. Persyaratan kriteria sesuai dengan tingkat kepentingan yang telah ditentukan oleh pihak MTs diantaranya yaitu nilai ujian nasional, nilai tes Al-Quran, dan nilai tes potensi akademik. Penyeleksian oleh MTs Negeri Kisaran masih dilakukan secara manual, sehingga membutuhkan waktu relatif lebih lama dan sering terjadi kesalahan yang dapat mempengaruhi hasil analisis. Untuk menghadapi masalah tersebut, dalam penyeleksian penerimaan calon peserta didik baru diperlukan adanya sistem pendukung keputusan yang sesuai.

Sistem Pendukung Keputusan (SPK) merupakan suatu sistem alat bantu komputer untuk mencari solusi yang tepat dari suatu permasalahan yang dihadapi. Menurut Kusumadewi dkk. (2006), Multi Attribute Decision Making (MADM) adalah salah satu metode pengambil keputusan untuk menetapkan alternatif terbaik dari sejumlah alternatif berdasarkan beberapa kriteria tertentu. Terdapat beberapa metode yang dapat digunakan untuk menyelesaikan masalah MADM diantaranya yaitu Simple Additive Weighting (SAW), dan Weighted Aggregated Sum Product Assesmen (WASPAS). Konsep dasar SAW adalah mencari penjumlahan terbobot dari rating kinerja pada setiap alternatif di 
semua kriteria. Sedangkan metode WASPAS merupakan metode gabungan yang terdiri dari metode SAW dan metode Weighted Product (WP). Konsep metode WP sendiri yaitu nilai rating kinerja pada setiap alternatif dipangkatkan dengan bobot setiap kriteria yang bersangkutan. Metode WASPAS memiliki tahap perhitungan yang sama dengan metode SAW, hanya saja penggabungannya terletak pada rumus kombinasi linier metode SAW dan WP untuk menentukan nilai preferensi pada setiap alternatif.

Pembobot sangat penting diperlukan dalam penyelesaian masalah menggunakan MADM, di sini penulis menggunakan metode pembobotan Rank Order Centroid (ROC). Menurut Jeffreys dan Cockfield dalam Rahma (2013), teknik ROC memberikan bobot pada setiap kriteria sesuai dengan ranking yang dinilai berdasarkan tingkat prioritas. Penelitian ini menggunakan Graphical User Interface (GUI) Matlab sebagai alat komputasi untuk melakukan pengambilan keputusan dan dilanjutkan dengan uji analisis sensitivitas untuk mengetahui metode terbaik agar mendapatkan hasil yang maksimal.

\section{TINJAUAN PUSTAKA}

\subsection{Seleksi Penerimaan Peserta Didik Baru}

Seleksi penerimaan peserta didik baru adalah kegiatan awal yang dilakukan oleh sekolah dalam melakukan penyaringan sumber daya manusia (SDM) yang berkualitas demi membantu kelancaran tugas suatu sekolah. Sekolah dapat menentukan kriteriakriteria peserta didik baru yang dapat diterima dan cara yang digunakan dalam pelaksanaan kegiatan seleksi tersebut. Tahapan seleksi yang ditetapkan berbeda untuk masing-masing sekolah, sehingga kriteria dan teknik penilaiannya pun berbeda-beda.

\subsection{Sistem Pendukung Keputusan (SPK)}

Menurut Turban (1990), menyebutkan bahwa konsep sistem pendukung keputusan (SPK) sebagai sistem interaktif berbasis komputer yang dapat membantu seseorang dalam mengambil keputusan. SPK berguna untuk dapat mengatasi permasalahan yang dihadapi sehingga mendapatkan solusi yang tepat bagi tiap alternatifnya.

\subsection{Metode Multi Attribute Decision Making (MADM)}

Menurut Kusumadewi dkk. (2006) MADM merupakan salah satu metode pengambil keputusan untuk menetapkan alternatif terbaik dari sejumlah alternatif berdasarkan beberapa kriteria tertentu. MADM biasanya digunakan untuk melakukan penilaian atau seleksi terhadap alternatif. Tujuan MADM adalah mengevaluasi alternatif $A_{i}$ ( $\mathrm{i}=1,2, \ldots, \mathrm{m})$ terhadap sekumpulan kriteria $\mathrm{C}_{\mathrm{j}}(\mathrm{j}=1,2, \ldots, \mathrm{n})$ setiap kriteria tidak saling bergantung satu dengan yang lainnya. Langkah metode MADM dimulai dengan membuat matriks keputusan $(\mathbf{X})$ dan kemudian menentukan nilai bobot. Matriks keputusan setiap alternatif terhadap setiap kriteria diberikan sebagai berikut:

$$
\mathbf{X}=\left[\begin{array}{cccc}
x_{11} & x_{12} & \ldots & x_{1 n} \\
x_{21} & x_{22} & \ldots & x_{2 n} \\
\vdots & \vdots & & \vdots \\
x_{m 1} & x_{m 2} & \ldots & x_{m n}
\end{array}\right]
$$

Nilai bobot menunjukkan tingkat kepentingan relatif setiap kriteria dan dihitung menggunakan rumus pembobotan ROC, sehingga dapat ditulis sebagai berikut:

$$
\mathbf{w}=\left[\begin{array}{llll}
\mathrm{w}_{1} & \mathrm{w}_{2} & \ldots & \mathrm{w}_{\mathrm{n}}
\end{array}\right]
$$

\subsection{Pembobotan Rank Order Centroid (ROC)}

Menurut Jeffreys dan Cockfield dalam Rahma (2013), teknik ROC memberikan bobot pada setiap kriteria sesuai dengan ranking yang dinilai berdasarkan tingkat prioritas. 
Kelebihan pembobotan ROC yaitu pengambil keputusan dapat menentukan urutan tingkat prioritas tersebut dimulai dari urutan peringkat ke-1 dan seterusnya yang menunjukkan kriteria yang lebih diprioritaskan hingga akhir kriteria. Misalnya terdapat $\mathrm{n}$ kriteria, dengan "kriteria 1 lebih penting dari kriteria 2, kriteria 2 lebih penting dari kriteria 3" dan seterusnya hingga kriteria ke-n, maka $\mathrm{w}_{1} \geq \mathrm{w}_{2} \geq \mathrm{w}_{3} \geq \ldots \geq \mathrm{w}_{\mathrm{n}}$. Sehingga dapat dirumuskan sebagai berikut:

$$
\mathrm{W}_{\mathrm{j}}=\frac{1}{n} \sum_{k=j}^{n} \frac{1}{k}
$$

dengan $\mathrm{j}=1,2, \ldots, \mathrm{n}$

keterangan: $\mathrm{w}_{\mathrm{j}}=$ bobot kriteria ke- $\mathrm{j}$

$\mathrm{n}=$ banyaknya kriteria

sehingga dapat ditulis:

$$
\mathbf{w}=\left[\begin{array}{llll}
\mathrm{w}_{1} & \mathrm{w}_{2} & \ldots & \mathrm{w}_{\mathrm{n}}
\end{array}\right]
$$

\subsection{Metode Simple Additive Weighting (SAW)}

Konsep dasar metode SAW adalah mencari penjumlahan terbobot dari rating kinerja pada setiap alternatif pada semua kriteria (Fishburn dalam Kusumadewi dkk., 2006). Metode SAW membutuhkan proses normalisasi matriks keputusan (X) ke suatu skala yang dapat diperbandingkan dengan semua rating alternatif yang ada. Berikut rumus untuk melakukan proses normalisasi tersebut:

$$
r_{i j} \begin{cases}\frac{x_{i j}}{\operatorname{Max}_{i} x_{i j}} & \text { (kriteria keuntungan (benefit) } \\ \frac{{ }_{i} x_{i j} x_{i j}}{x_{i j}} & \text { (kriteria biaya (cost) }\end{cases}
$$

Dimana $r_{i j}$ adalah rating kinerja ternormalisasi dari alternatif $A_{i}$ pada kriteria $C_{j} ; i=1,2, \ldots, m$ dan $\mathrm{j}=1,2, \ldots, \mathrm{n}$.

Nilai preferensi untuk tiap alternatif diberikan sebagai berikut:

$$
\mathrm{Q}^{(1)}=\sum_{j=1}^{n} r_{i j} \cdot w_{j}
$$

\subsection{Metode Weighted Aggregated Sum Product Assesmen (WASPAS)}

Metode Weighted Aggregated Sum Product Assesmen (WASPAS) merupakan metode gabungan yang terdiri dari metode SAW dan metode WP. Metode Weighted Product (WP) sendiri yaitu nilai rating kinerja pada setiap alternatif dipangkatkan dengan bobot setiap kriteria yang bersangkutan (Yoon, 1989) dalam Kusumadewi dkk. (2006). Menurut Zavadskas dkk. (2012), prosedur metode WASPAS mencakup beberapa langkah yaitu:

1. Melakukan normalisasi matriks keputusan (X) sehingga membentuk matriks ternormalisasi (R) dengan rumus seperti pada Persamaan (5).

2. Menghitung nilai preferensi dari alternatif ke-i, berdasarkan metode SAW sebagai berikut:

$$
\mathrm{Q}_{\mathrm{i}}^{(1)}=\sum_{j=1}^{n} r_{i j} . w_{j} ; \text { dengan } \mathrm{i}=1,2, \ldots, \mathrm{m} ; \mathrm{j}=1,2, \ldots, \mathrm{n}
$$

3. Menghitung nilai preferensi dari alternatif ke-i, berdasarkan metode WP sebagai berikut:

$$
\mathrm{Q}_{\mathrm{i}}{ }^{(2)}=\prod_{j=1}^{n}\left(r_{i j}\right)^{w_{j}} ; \text { dengan } \mathrm{i}=1,2, \ldots, \mathrm{m} ; \mathrm{j}=1,2, \ldots, \mathrm{n}
$$

4. Menghitung nilai preferensi dari alternatif ke-i, berdasarkan metode WASPAS sebagai berikut:

$$
\mathrm{Q}_{\mathrm{i}}=\lambda \cdot \mathrm{Qi}^{(1)}+(1-\lambda) \cdot \mathrm{Qi}^{(2)}
$$

sehingga

$$
\mathrm{Q}_{\mathrm{i}}=\lambda \cdot\left(\sum_{j=1}^{n} r_{i j} \cdot w_{j}\right)+(1-\lambda) \cdot\left(\prod_{j=1}^{n}\left(r_{i j}\right)^{w_{j}}\right)
$$


nilai $\lambda$ merupakan nilai kontribusi antara metode SAW dan WASPAS yang setara, dimana nilai $\lambda$ berkisar $0-1$ sesuai dengan ketetapan diperoleh nilai $\lambda=0,5$ (Zavadskas dkk., 2012).

\subsection{Analisis Sensitivitas}

Menurut Yeh (2002), proses pengujian sensitivitas dilakukan dengan cara mencari derajat sensitivitas setiap kriteria terhadap hasil perankingan pada setiap metode MADM. Derajat sensitivitas merupakan nilai perubahan ranking yang diperoleh setelah menaikkan nilai bobot pada salah satu kriteria kemudian diterapkan pada setiap metode, selanjutnya dibandingkan saat bobot awal. Derajat sensitivitas setiap kriteria diperoleh melalui langkah-langkah sebagai berikut:

1. Ubah bobot suatu kriteria dengan menaikkan bobot sebesar 0,1 , sementara bobot kriteria lainnya masih bernilai tetap.

2. Lakukan normalisasi bobot kriteria tersebut dengan cara membagi bobot sebesar 1,1 sehingga membentuk nilai bobot $\sum w_{j}=1$.

3. Aplikasikan bobot-bobot kriteria yang telah diperoleh pada metode SAW dan WASPAS.

4. Hitung prosentase perubahan ranking (derajat sensitivitas) untuk masing-masing metode yaitu SAW dan WASPAS dengan cara membandingkan berapa banyak perubahan ranking yang terjadi jika dibandingkan dengan kondisi pada saat bobot awal. Prosentase perubahan ranking dari peringkat ke-i dapat dihitung dengan rumus berikut:

$$
\frac{\text { (Preferensi peringkat ke } \left.\mathrm{i}-\left(\text { Preferensi peringkat ke } \mathrm{i}_{\mathrm{ROC}}\right)\right)}{\text { Preferensi peringkat ke } \mathrm{i}_{\mathrm{ROC}}} x(100 \%)
$$

\subsection{Komputasi Graphical User Interface (GUI) Matlab}

Matlab merupakan perangkat lunak yang cocok dipakai sebagai alat komputasi yang melibatkan penggunaan matriks dan vektor (Siang, 2009). Menurut Sugiharto (2006), GUIDE atau GUI builder merupakan sebuah Graphical User Interface (GUI) yang dibangun dengan obyek grafis seperti tombol (button), kotak teks, slider, sumbu (axes), maupun menu.

\section{METODE PENELITIAN}

\subsection{Jenis dan Sumber Data}

Data yang digunakan merupakan data sekunder yang diperoleh dari Madrasah Tsanawiyah (MTs) Negeri Kisaran Kabupaten Asahan Provinsi Sumatera Utara. Data yang diambil yaitu data seleksi penerimaan peserta didik baru tahun ajaran 2018/2019 yang dilakukan di lembaga pendidikan tersebut. Data yang diambil sebanyak 422 data yang terdiri dari 192 data peserta didik yang diterima dan 230 data peserta didik lainnya tidak diterima.

\subsection{Variabel Penelitian}

1. Alternatif $\left(\mathrm{A}_{\mathrm{i}}\right)$

Variabel alternatif $\left(A_{i}, i=1,2, \ldots, 422\right)$ untuk studi kasus ini adalah sebanyak 422 calon peserta didik yang diterima maupun tidak diterima.

2. Kriteria $\left(\mathrm{C}_{\mathrm{j}}\right)$

Variabel kriteria untuk studi kasus ini diantaranya yaitu:

$\mathrm{C}_{1}$ : Nilai Ujian Nasional

$\mathrm{C}_{2}$ : Nilai Tes Al-Qur'an

$\mathrm{C}_{3}$ : Nilai Tes Potensi Akademik 
Dari kriteria diatas dapat ditentukan bahwa $\mathrm{C}_{1}, \mathrm{C}_{2}$, dan $\mathrm{C}_{3}$ merupakan kriteria keuntungan (benefit).

\subsection{Langkah Analisis}

1. Mencari bobot menggunakan pembobotan Rank Order Centroid (ROC)

a. Menentukan kepentingan tiap kriteria.

b. Perhitungan bobot ROC.

2. Simple Additive Weighting (SAW)

a. Membuat matriks keputusan (X) seperti pada Persamaan (1).

b. Melakukan normalisasi matriks keputusan sehingga membentuk matriks ternormalisasi $(\mathbf{R})$.

c. Menentukan bobot preferensi atau tingkat kepentingan (w) setiap kriteria memakai bobot yang sudah dihitung menggunakan pembobotan ROC.

d. Menentukan nilai preferensi $\left(\mathrm{Q}^{\left({ }^{(1)}\right.}\right)$ untuk setiap alternatif

e. Menentukan peserta didik yang diterima dengan melihat nilai preferensi $\left(\mathrm{Q}_{\mathrm{i}}{ }^{(1)}\right)$ terbesar.

3. Weighted Aggregated Sum Product Assesmen (WASPAS)

a. Membuat matriks keputusan (X) seperti pada Persamaan (1).

b. Melakukan normalisasi matriks keputusan sehingga membentuk matriks ternormalisasi $(\mathbf{R})$.

c. Menentukan bobot preferensi atau tingkat kepentingan (w) setiap kriteria memakai bobot yang sudah dihitung menggunakan pembobotan ROC.

d. Menghitung total nilai preferensi $\left(Q_{i}\right)$ untuk setiap alternatif.

e. Menentukan peserta didik yang diterima dengan melihat nilai preferensi $\left(\mathrm{Q}_{\mathrm{i}}\right)$ terbesar.

4. Melakukan analisis sensitivitas untuk memilih metode terbaik.

\section{HASIL DAN PEMBAHASAN}

\subsection{Deskripsi Data}

Tabel 1. Deskripsi Data Keseluruhan

\begin{tabular}{ccccc}
\hline Data & $\mathrm{N}$ & Minimum & Maximum & Rata-rata \\
\hline $\mathrm{C}_{1}$ & 422 & 193,1 & 293,1 & 259,27585 \\
$\mathrm{C}_{2}$ & 422 & 22 & 99 & 70,86493 \\
$\mathrm{C}_{3}$ & 422 & 8,67 & 34,8 & 19,30900
\end{tabular}

Berdasarkan Tabel.1, dapat dilihat bahwa jumlah pendaftar calon peserta didik baru Madrasah Tsanawiyah (MTs) Negeri Kisaran yaitu sebanyak 422 pendaftar. Data tersebut memiliki 3 (tiga) variabel kriteria penilaian, diantaranya yaitu $C_{1}$ : Nilai Ujian Nasional, $C_{2}$ : Nilai Tes Al-Qur'an, dan $\mathrm{C}_{3}$ : Nilai Tes Potensi Akademik. Jumlah yang diterima sebanyak 192 calon peserta didik dan 230 calon peserta didik lainnya tidak diterima.

\subsection{Perhitungan Bobot Rank Order Centroid (ROC)}

Berdasarkan kriteria yang digunakan dalam penelitian ini, sesuai dengan urutan tingkat prioritas kriteria yang ditetapkan oleh Madrasah Tsanawiyah (MTs) Negeri Kisaran dapat dituliskan bahwa:

Kriteria nilai ujian nasional $\geq$ kriteria nilai tes Al-Qur'an $\geq$ kriteria nilai tes potensi akademik. 
Maka: $\mathrm{w}_{1} \geq \mathrm{w}_{2} \geq \mathrm{w}_{3}$

Perhitungan dalam menentukan bobot rank order centroid (ROC) ditunjukkan sebagai berikut:

$$
\begin{aligned}
& \mathrm{w}_{1}=\frac{1}{n} \sum_{k=1}^{3} \frac{1}{k}=\frac{1+\frac{1}{2}+\frac{1}{3}}{3}=0,61111 \\
& \mathrm{w}_{2}==\frac{1}{n} \sum_{k=2}^{3} \frac{1}{k}=\frac{\frac{1}{2}+\frac{1}{3}}{3}=0,27778 \\
& \mathrm{w}_{3}==\frac{1}{n} \sum_{k=3}^{3} \frac{1}{k}=\frac{\frac{1}{3}}{3}=0,11111
\end{aligned}
$$

Sehingga diperoleh nilai bobot ROC $\left(\mathrm{w}_{\mathrm{j}}\right)$ sebagai berikut:

$$
\mathbf{w}=[0,611110,277780,11111]
$$

\subsection{Perhitungan Metode Simple Additive Weighted (SAW)}

a. Membuat matriks keputusan (X)

$$
\mathbf{X}=\left[\begin{array}{ccc}
264,5 & 80 & 20,53 \\
281,8 & 89 & 11,60 \\
\vdots & \vdots & \vdots \\
276,4 & 70 & 21,53
\end{array}\right]
$$

b. Melakukan Normalisasi

Seluruh kriteria yang digunakan dalam penelitian ini merupakan kriteria keuntungan (benefit). Selanjutnya dilakukan normalisasi dengan rumus seperti pada Persamaan (5), sehingga diperoleh matriks ternormalisasi $(\mathbf{R})$ sebagai berikut:

Tabel 2. Matriks Ternormalisasi $(\mathbf{R})$

\begin{tabular}{clll}
\hline \multirow{2}{*}{ Alternatif } & \multicolumn{3}{c}{ Kriteria } \\
\cline { 2 - 4 } & $\mathrm{C}_{1}$ & $\mathrm{C}_{2}$ & $\mathrm{C}_{3}$ \\
\hline $\mathrm{A}_{1}$ & 0,90242 & 0,80808 & 0,59004 \\
$\mathrm{~A}_{2}$ & 0,96145 & 0,89899 & 0,33333 \\
$\vdots$ & $\vdots$ & $\vdots$ & $\vdots$ \\
$\mathrm{A}_{422}$ & 0,94302 & 0,70707 & 0,61877 \\
\hline
\end{tabular}

c. Menentukan nilai preferensi SAW dan melakukan perangkingan

Perhitungan nilai preferensi SAW seperti pada Persamaan (6), sehingga diperoleh nilai sebagai berikut:

Tabel 3. Nilai Preferensi SAW

\begin{tabular}{cc}
\hline Alternatif & $\mathrm{Q}^{(1)}$ \\
\hline $\mathrm{A}_{1}$ & 0,84151 \\
$\mathrm{~A}_{2}$ & 0,87431 \\
$\vdots$ & $\vdots$ \\
$\mathrm{A}_{100}$ & 0,86594 \\
$\vdots$ & $\vdots$ \\
$\mathrm{A}_{200}$ & 0,77347 \\
$\vdots$ & $\vdots$ \\
$\mathrm{A}_{300}$ & 0,78730 \\
$\vdots$ & $\vdots$ \\
$\mathrm{A}_{422}$ & 0,84145 \\
\hline
\end{tabular}

Tabel 4. Peringkat Nilai Preferensi SAW

\begin{tabular}{ccc}
\hline Peringkat & $\mathrm{Q}_{\mathrm{i}}{ }^{(1)}$ & Alternatif \\
\hline 1 & 0,94634 & $\mathrm{~A}_{171}$ \\
2 & 0,93688 & $\mathrm{~A}_{203}$ \\
$\vdots$ & $\vdots$ & $\vdots$ \\
100 & 0,84460 & $\mathrm{~A}_{240}$ \\
$\vdots$ & $\vdots$ & $\vdots$ \\
200 & 0,80619 & $\mathrm{~A}_{187}$ \\
$\vdots$ & $\vdots$ & $\vdots$ \\
300 & 0,76609 & $\mathrm{~A}_{279}$ \\
$\vdots$ & $\vdots$ & $\vdots$ \\
422 & 0,63424 & $\mathrm{~A}_{215}$ \\
\hline
\end{tabular}


4.4.Perhitungan Metode Weighted Aggregated Sum Product Assesmen (WASPAS)

a. Membuat matriks keputusan $(\mathbf{X})$

$$
\mathbf{X}=\left[\begin{array}{ccc}
264,5 & 80 & 20,53 \\
281,8 & 89 & 11,60 \\
\vdots & \vdots & \vdots \\
276,4 & 70 & 21,53
\end{array}\right]
$$

b. Melakukan Normalisasi

Seluruh kriteria yang digunakan dalam penelitian ini merupakan kriteria keuntungan (benefit). Selanjutnya dilakukan normalisasi dengan rumus seperti pada Persamaan (5), sehingga diperoleh matriks ternormalisasi (R) seperti pada Tabel 2.

c. Menentukan nilai preferensi WASPAS dan melakukan perangkingan

Perhitungan nilai preferensi WASPAS seperti pada Persamaan (10), sehingga diperoleh nilai sebagai berikut:

Tabel 5. Nilai Preferensi WASPAS

\begin{tabular}{cc}
\hline Alternatif & $\mathrm{Q}_{\mathrm{i}}$ \\
\hline $\mathrm{A}_{1}$ & 0,83816 \\
$\mathrm{~A}_{2}$ & 0,85660 \\
$\vdots$ & $\vdots$ \\
$\mathrm{A}_{100}$ & 0,85425 \\
$\vdots$ & $\vdots$ \\
$\mathrm{A}_{200}$ & 0,76885 \\
$\vdots$ & $\vdots$ \\
$\mathrm{A}_{300}$ & 0,77355 \\
$\vdots$ & $\vdots$ \\
$\mathrm{A}_{422}$ & 0,83608 \\
\hline
\end{tabular}

\subsection{Analisis Sensitivitas}

Tabel 6. Peringkat Nilai Preferensi WASPAS

Perankingan calon peserta didik baru yang dihasilkan pada metode SAW dan WASPAS menunjukkan hasil yang berbeda, sehingga dalam menentukan metode terbaik perlu dilakukan analisis sensitivitas. Berikut merupakan langkah-langkah analisis sensitivitas:

a. Mengubah bobot ROC dengan menaikkan bobot sebesar 0,1 sementara bobot lainnya bernilai tetap.

Nilai bobot ROC telah dihitung dan diperoleh nilai pada Persamaan (12) sebagai berikut: $\mathbf{w}=[0,61111 ; 0,27778 ; 0,11111]$.

Tabel 7. Nilai Bobot $\mathrm{C}_{1}$ diubah

\begin{tabular}{cccc}
\hline W1 & W2 & W3 & Total \\
\hline 0,71111 & 0,37778 & 0,11111 & 1,1 \\
\hline
\end{tabular}

Tabel 8. Nilai Bobot $\mathrm{C}_{2}$ diubah

\begin{tabular}{cccc}
\hline $\mathbf{w 1}$ & $\mathbf{w 2}$ & $\mathbf{W 3}$ & Total \\
\hline 0,61111 & 0,37778 & 0,11111 & 1,1 \\
\hline
\end{tabular}


Tabel 9. Nilai Bobot $\mathrm{C}_{3}$ diubah

\begin{tabular}{cccc}
\hline w1 & w2 & w3 & Total \\
\hline 0,61111 & 0,37778 & 0,11111 & 1,1 \\
\hline
\end{tabular}

b. Melakukan normalisasi bobot pada tiap kriteria yang telah diperoleh pada langkah (a) dengan cara membagi bobot sebesar 1,1.

Tabel 10. Normalisasi Nilai Bobot $\mathrm{C}_{1}$

\begin{tabular}{cccc|c|}
\hline $\mathbf{w 1}$ & $\mathbf{w} 2$ & $\mathbf{W 3}$ & Total \\
\cline { 1 - 1 }$\frac{0,71111}{1,1}$ & $\frac{0,27778}{1,1}$ & $\frac{0,11111}{1,1}$ & \\
\cline { 1 - 1 } 0,64646 & 0,25253 & 0,10101 & 1 \\
\hline
\end{tabular}

Tabel 11. Normalisasi Nilai Bobot $\mathrm{C}_{2}$

\begin{tabular}{cccc|c|}
\hline $\mathbf{w 1}$ & $\mathbf{w} 2$ & $\mathbf{W 3}$ & Total \\
\cline { 1 - 1 }$\frac{0,61111}{1,1}$ & $\frac{0,37778}{1,1}$ & $\frac{0,11111}{1,1}$ & \\
\cline { 1 - 1 } & $\frac{1,55556}{0,34343}$ & 0,10101 & 1 \\
\hline
\end{tabular}

Tabel 12. Normalisasi Nilai Bobot $\mathrm{C}_{3}$

\begin{tabular}{cccc|c|}
\hline $\mathbf{W 1}$ & $\mathbf{W} 2$ & $\mathbf{W 3}$ & Total \\
\cline { 1 - 1 }$\frac{0,61111}{1,1}$ & $\frac{0,27778}{1,1}$ & & $\frac{0,21111}{1,1}$ & \\
\cline { 1 - 1 } & $\frac{1,55556}{0,25253}$ & 0,19192 & 1 \\
\hline
\end{tabular}

c. Mengaplikasikan bobot kriteria baru yang telah diperoleh pada langkah (b) dalam metode SAW dan WASPAS.

Tabel 13. Preferensi Metode SAW ROC dan WASPAS ROC

\begin{tabular}{ccccc}
\hline Peringkat & Alternatif & SAW ROC & Alternatif & WASPAS ROC \\
\hline 1 & $\mathrm{~A}_{171}$ & 0,94634 & $\mathrm{~A}_{171}$ & 0,94222 \\
2 & $\mathrm{~A}_{203}$ & 0,93688 & $\mathrm{~A}_{125}$ & 0,92878 \\
$\vdots$ & $\vdots$ & $\vdots$ & $\vdots$ & $\vdots$ \\
70 & $\mathrm{~A}_{13}$ & 0,85849 & $\mathrm{~A}_{243}$ & 0,85357 \\
$\vdots$ & $\vdots$ & $\vdots$ & $\vdots$ & $\vdots$ \\
140 & $\mathrm{~A}_{355}$ & 0,82979 & $\mathrm{~A}_{79}$ & 0,82348 \\
$\vdots$ & $\vdots$ & $\vdots$ & $\vdots$ & $\vdots$ \\
192 & $\mathrm{~A}_{291}$ & 0,81083 & $\mathrm{~A}_{225}$ & 0,80389 \\
\hline
\end{tabular}

Tabel 14. Preferensi Metode SAW pada Perubahan Bobot

\begin{tabular}{|c|c|c|c|c|c|c|}
\hline Peringkat & Alternatif & SAW 1 & Alternatif & SAW 2 & Alternatif & SAW 3 \\
\hline 1 & $\mathrm{~A}_{171}$ & 0,95056 & $\mathrm{~A}_{171}$ & 0,94846 & $\mathrm{~A}_{171}$ & 0,91778 \\
\hline 2 & $\mathrm{~A}_{203}$ & 0,94165 & $\mathrm{~A}_{203}$ & 0,94170 & $\mathrm{~A}_{208}$ & 0,91744 \\
\hline$\vdots$ & $\vdots$ & $\vdots$ & $\vdots$ & $\vdots$ & $\vdots$ & $\vdots$ \\
\hline 70 & $\mathrm{~A}_{233}$ & 0,86359 & $\mathrm{~A}_{8}$ & 0,85667 & $\mathrm{~A}_{96}$ & 0,83208 \\
\hline$\vdots$ & $\vdots$ & $\vdots$ & $\vdots$ & $\vdots$ & $\vdots$ & $\vdots$ \\
\hline 140 & $\mathrm{~A}_{238}$ & 0,83690 & $\mathrm{~A}_{374}$ & 0,82649 & $\mathrm{~A}_{323}$ & 0,80674 \\
\hline$\vdots$ & $\vdots$ & $\vdots$ & $\vdots$ & $\vdots$ & $\vdots$ & $\vdots$ \\
\hline 192 & $\mathrm{~A}_{48}$ & 0,81825 & $\mathrm{~A}_{115}$ & 0,80104 & $\mathrm{~A}_{121}$ & 0,78953 \\
\hline
\end{tabular}


Tabel 15. Preferensi Metode WASPAS pada Perubahan Bobot

\begin{tabular}{|c|c|c|c|c|c|c|}
\hline \multicolumn{2}{|c|}{ Peringkat Alternatif } & $\begin{array}{c}\text { WASPAS } \\
1\end{array}$ & Alternatif & $\begin{array}{c}\text { WASPAS } \\
2\end{array}$ & Alternatif & $\begin{array}{c}\text { WASPAS } \\
3 \\
\end{array}$ \\
\hline 1 & $\mathrm{~A}_{171}$ & 0,94676 & $\mathrm{~A}_{171}$ & 0,94470 & $\mathrm{~A}_{208}$ & 0,91622 \\
\hline 2 & $\mathrm{~A}_{125}$ & 0,93481 & $\mathrm{~A}_{203}$ & 0,93409 & $\mathrm{~A}_{171}$ & 0,91141 \\
\hline$\vdots$ & $\vdots$ & $\vdots$ & $\vdots$ & $\vdots$ & $\vdots$ & $\vdots$ \\
\hline 70 & $\mathrm{~A}_{344}$ & 0,85923 & $\mathrm{~A}_{181}$ & 0,85003 & $\mathrm{~A}_{181}$ & 0,82608 \\
\hline$\vdots$ & $\vdots$ & $\vdots$ & $\vdots$ & $\vdots$ & $\vdots$ & $\vdots$ \\
\hline 140 & $\mathrm{~A}_{363}$ & 0,82982 & $\mathrm{~A}_{400}$ & 0,82097 & $\mathrm{~A}_{210}$ & 0,79575 \\
\hline$\vdots$ & $\vdots$ & $\vdots$ & $\vdots$ & $\vdots$ & $\vdots$ & $\vdots$ \\
\hline 192 & $\mathrm{~A}_{258}$ & 0,81168 & $\mathrm{~A}_{112}$ & 0,79393 & $\mathrm{~A}_{348}$ & 0,77922 \\
\hline
\end{tabular}

d. Hitung prosentase perubahan ranking (derajat sensitivitas)

Prosentase perubahan ranking yang dihitung berdasarkan 192 alternatif terbaik dilakukan dengan cara membandingkan berapa banyak perubahan ranking yang terjadi jika dibandingkan dengan saat menggunakan bobot ROC. Prosentase perubahan ranking dari peringkat ke-i dapat dihitung dengan rumus seperti pada Persamaan (11). Sehingga diperoleh nilai prosentase sensitivitas sebagai berikut:

Tabel 16. Prosentase Sensitivitas

\begin{tabular}{ccc}
\hline Kriteria & SAW & WASPAS \\
\hline $\mathrm{C}_{1}$ & 0,70040 & 0,73112 \\
$\mathrm{C}_{2}$ & $-0,28070$ & $-0,22260$ \\
$\mathrm{C}_{3}$ & $-2,87337$ & $-3,10707$ \\
\hline Rata-rata & $-0,81789$ & $-0,86619$ \\
\hline
\end{tabular}

Berdasarkan Tabel 16 diperoleh nilai rata-rata prosentase sensitivitas metode SAW sebesar $-0,82 \%$ sedangkan metode WASPAS sebesar $-0,87 \%$. Hal ini dapat disimpulkan bahwa metode yang paling tepat yang bisa digunakan untuk memperoleh alternatif terbaik yang optimal pada kasus seleksi penerimaan calon peserta didik baru di Madrasah Tsanawiyah (MTs) Negeri Kisaran adalah metode SAW.

\subsection{GUI Matlab Metode SAW dan WASPAS}

a. Layar Utama

Tampilan pada Gambar 1 merupakan tampilan layar utama. Kemudian klik tombol "START" untuk terhubung ke layar kedua.

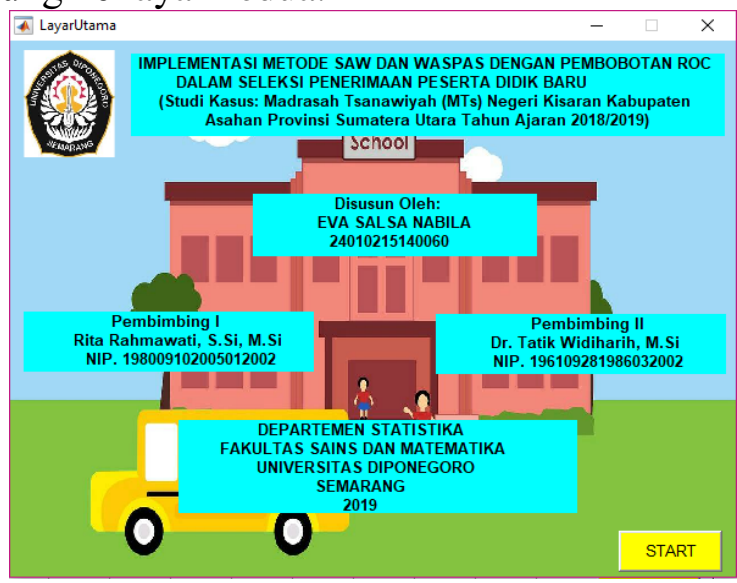

Gambar 1. Tampilan Layar Utama 
b. Layar Kedua

Layar kedua berisikan alternatif dan kriteria penilaian. Selanjutnya klik tombol "MULAI ANALISIS" untuk terhubung pada layar ketiga dan memulai analisis. Klik tombol "BACK" untuk kembali ke layar utama.

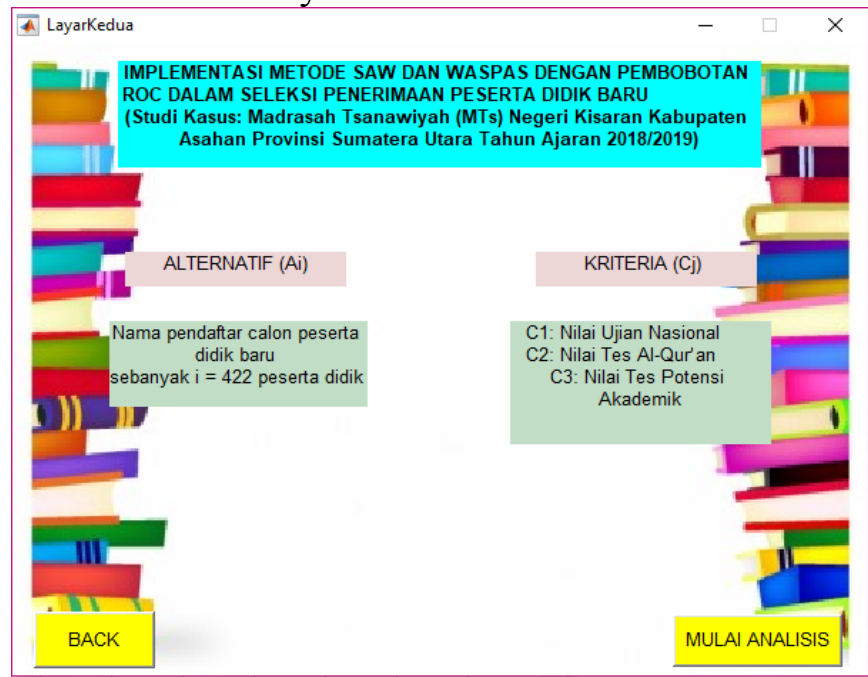

Gambar 2. Tampilan Layar Kedua

c. Layar Ketiga

Layar ketiga berisikan analisis perhitungan metode SAW dan WASPAS. Klik "BACK" untuk menampilkan kembali layar kedua. Klik "RESET" untuk mengulang dan menghapus hasil perhitungan. Klik "NEXT" agar terhubung pada layar keempat untuk melakukan analisis sensitivitas.

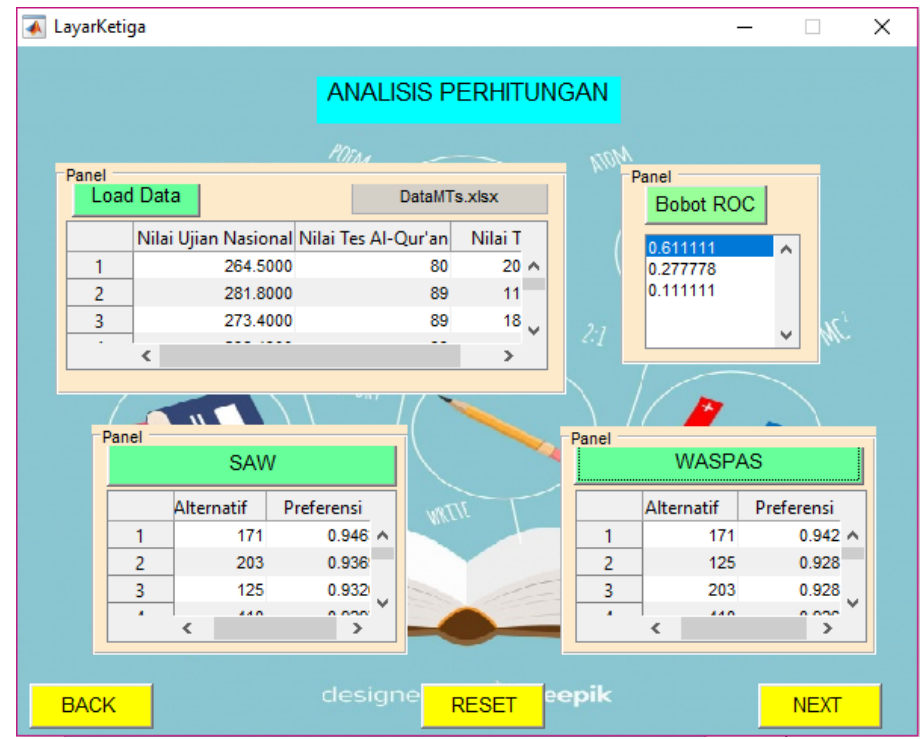

Gambar 3. Hasil Perhitungan SAW dan WASPAS 


\section{d. Layar Keempat}

Layar keempat berisikan perhitungan analisis sensitivitas. Klik "BACK" untuk menampilkan kembali layar ketiga. Klik "RESET" untuk mengulang dan menghapus hasil perhitungan. Klik "EXIT” untuk keluar.

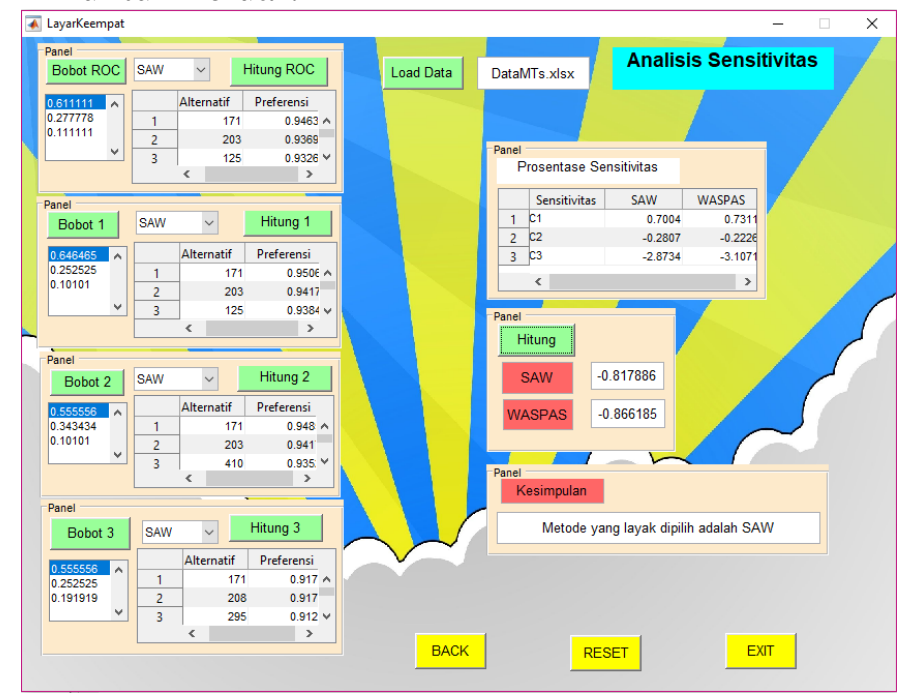

Gambar 4. Hasil Perhitungan Analisis Sensitivitas

\section{KESIMPULAN}

Berdasarkan analisis hasil dan pembahasan yang telah dijelaskan sebelumnya, dapat diambil beberapa kesimpulan, diantaranya yaitu:

1. Nilai bobot ROC yang diperoleh adalah $\mathrm{w}_{1}=0,61111 ; \mathrm{w}_{2}=0,27778$; dan $\mathrm{w}_{3}=0,11111$. Nilai bobot ROC tersebut baik dan cocok digunakan dalam proses seleksi penerimaan calon peserta didik baru di Madrasah Tsanawiyah (MTs) Negeri Kisaran.

2. Nilai rata-rata prosentase sensitivitas yang diperoleh untuk metode SAW $(-0,82 \%)$ lebih besar dibandingkan metode WASPAS (-0,87\%). Sehingga dapat disimpulkan bahwa metode yang paling tepat yang bisa digunakan pada kasus ini adalah metode SAW.

\section{DAFTAR PUSTAKA}

Kusumadewi, S., Hartati, S., Harjoko, A., dan Wardoyo, R. 2006. Fuzzy Multi-Attribute Decision Making (FUZZY MADM). Yogyakarta: Graha Ilmu.

Rahma, A. 2013. Sistem Pendukung Keputusan Seleksi Masuk Mahasiswa Menggunakan Metode SMARTER. Jurnal. Bandung: Universitas Pendidikan Indonesia.

Siang, J.J. 2009. Jaringan Syaraf Tiruan dan Pemrograman menggunakan Matlab. Yogyakarta : Penerbit ANDI.

Sugiharto, Aris. 2006. Pemrograman GUI dengan MATLAB . Yogyakarta : Andi OFFSET.

Turban, E. 1990. Decision Support and Expert System: Management Support System. Mac Millan Pub. Co., New York.

Yeh, C. H. 2002. A Problem-Based Selection of Multi-Attribute Decision-Making Methods. Internasional Transactions In Operational Research. Blackwell Publishing, 169-181.

Zavadskas, E.K., Turskis, Z., Antucheviciene, J., Zakarevicius,A. 2012. Optimization of weighted aggregated sum product assessment. Electronics and Electrical Engineering, Vol. 122, No. 6, p.p. 36, 2012. 